\title{
The landforms associated with industrial placer gold mining in Siberia
}

\author{
JAROMÍR KOLEJKA
}

Masaryk University, Faculty of Education, Department of Geography, Brno, Czechia; Czech Academy of Sciences, Institute of Geonics, Department of Environmental Geography, Brno, Czechia; e-mail: kolejka@ped.muni.cz

ABSTRACT Industrial placer gold mining creates specific montane relief shapes. The character of these landforms is influenced by the mining technology used, the management of the site and mining area, the organization of the work and the subsequent measures after the termination of mining. Available classifications of known landforms can also be partially applied to shapes created during placer gold mining. Field research was conducted on gold-bearing fields in the upper courses of the Indigirka and Kolyma rivers. Drawn and photographic documentation of sample landforms was obtained, and their dimensions were ascertained, or their genesis was observed. The landforms found often differ in character and size from shapes known from other raw material mining and industrial gold panning sites. The mining landforms created during the industrial panning of gold in Siberia are documented by drawings according to the facts found during the field research. The text presents their basic differences from the hitherto known landforms.

KEY WORDS upper Indigirka and Kolyma Region - semi-arch heap - permafrost quarry - heap fields

KOLEJKA, J. (2022): The landforms associated with industrial placer gold mining in Siberia. Geografie, 127, 1, 31-54.

https://doi.org/10.37040/geografie2022127010031

Received September 2021, accepted December 2021.

(C) Česká geografická společnost, z. s., 2022 


\section{Introduction}

Placer mining is the main method of extracting gold grains from secondary deposit materials. This has been the case since ancient times, when humans realized the high exchange value of this metal. In many countries around the world, this method of gold mining has been used for a long time. Its origins can be traced back to the mid- $19^{\text {th }}$ century during the California Gold Rush. At that time, it became evident that artisanal (small manual) gold washing from unconsolidated sediments done by individuals or small groups of miners is not as effective as large-scale washing of deposits with the help of machines. The machines mainly replaced manual work when mining and transporting the rocks and during the actual washing with pumps driven by water jets. In this way, it was possible to process a large amount of material in a relatively short time, although not all the metal was obtained from the sediments. However, this method of mining also led to the production of a large amount of waste tailings, which had to be stored in a suitable place or handled further. Characteristic forms of relief are created both during the mining of gold-bearing rock and during the deposit of waste tailings.

Industrial gold panning is currently practiced in a number of countries around the world, but mostly in locations far from population centres. Such conditions are found regions where extreme natural characteristics limit other human economic activities. Examples are areas with permafrost (Russia, Canada, Alaska), tropical rainforests (Brazil, Peru) or extremely arid areas (Australia, Inner Mongolia in China - there are problems with securing sufficient volumes of water), where gold-bearing sediments of diverse origin and age are available. Although it is not possible to determine from the available information the share of gold from placer mining, it can objectively be assumed that gold washing affected large parts of the earth's surface, probably larger than underground mining, open air mining in quarries of hard gold-bearing rock and the impacts of chemical leaching. China (380 tons of gold) was at the forefront of current mining (in 2020), followed by Australia, Russia (300 tons) and the United States (Garside 2021). Gold production in Russia has been growing continuously in the last decade $(2020-300$ t, 2019 305 t, 2015 - 242 t, 2010 - 192 t, see Garside 2021).

However, it should be noted that data vary from source to source (see Metals Focus in World Gold Council 2020). The overall world boom in gold mining was triggered by the economic crisis in 2008. The growth of mining in Russia can also be attributed to a defensive response to economic sanctions by the US or the EU after the annexation of Crimea in 2014 (Grove 2017). In addition to the growth of production, the impacts on the natural environment also increased. The range of areas affected by opencast gold mining has increased by 400 to $600 \%$, depending on the region (Asner et al. 2013), as documented by an analysis of satellite images. So far, it has not been possible to separate the effects of large-scale industrial 
placer mining from small-scale individual mining. Small, artisanal placer gold mining is common in developing countries in Africa and Latin America (e.g. Ghana: Aryee, Ntibery, Atorkui 2003; Sudan: Addy 1998, Ille 2019; Benin: Grätz (2003); Burkina Faso: Luning 2008; Great Lakes region of East Africa: Macháček 2018; Bolivia and Peru, Philippines, Cambodia, India, etc.) However, it is far more inconspicuous than large-scale mining and is often carried out illegally in secret, and is currently even an attractive sport (e.g. Finland, Sweden, outside traditional mining countries).

\section{Landforms originating in the course of placer gold mining}

Regardless of the scale, intensity and extent of placer gold mining, vast volumes of rock need to be displaced. Industrial placer gold mining is gradually changing from a yield of $4 \mathrm{~g} \mathrm{Au} / \mathrm{t}$ raw material to $1 \mathrm{~g} \mathrm{Au} / \mathrm{t}$ (according to personal communication at the mining site, cf. Golubova 2017). This means that such washing of rock is also effective when only $1 \mathrm{~g}$ of gold is obtained from $1,000 \mathrm{~kg}$ of rock, i.e. one millionth of the weight of the processed raw material. In this respect, gold mining from ore veins is more efficient, where the concentrations of metal in the rock locally are many times higher. However, placer mining is technologically and organizationally less demanding, similar to prospecting and opening bearings.

Sedimentary gold deposits were formed as secondary concentrations of small and large corns of gold released from gold-bearing hard rock. These rocks were formed under suitable geochemical and geophysical conditions, often at the contact of magmatic intrusions into older rock massifs. Later they succumbed to weathering (solution and/or decay). The mineral gold, together with the weathering products, underwent fluvial transport and sedimentation in places of decrease in the transportation force of the watercourse. The most intense weathering leading to the formation of current sedimentary gold deposits probably took place in warm and humid climates (in the Paleogene and Neogene - for deposits in current geographic higher latitudes), while in the Pleistocene, there were frequent repeated transports and deposits (Englehardt et al. 2015). However, under suitable conditions, weathering products enriched with inert gold could remain in situ. Sedimentary gold deposits formed in ancient geological periods may have undergone metamorphosis, so gold may also occur in metamorphic rocks, although gold-bearing mineralization may have also taken place in other ways.

Specific landforms arise during both underground and open air gold mining. The landforms created by underground gold mining are very similar to the shapes created by underground mining of other ores, notwithstanding the smaller volumes of displaced rock by gold mining compared with those which originated by mining the ores of more abundant metals, unless gold is just a by-product 
in addition to other metals. Placer gold mining leads to the genesis of different forms. However, the volume of displaced rock can be many times larger here. Macháček $(2018,2019)$ describes the landforms created during small (artisanal) gold washing. Anthropogenic relief forms created during industrial placer mining are widely mentioned or visually documented in publications (see Bond, van Loon 2017, 2018; Casselman, ed. 2018; Lacy 2019; etc.), but their description and possible interpretation of genesis and classification is not paid attention to.

There is a large space devoted to mining landforms in the geomorphological literature. Mining (montane) activities result in montane landforms. According to their genesis and appearance, they are divided into the following classes: (1) convex (negative, excavated, dug); (2) concave (positive, piled, accumulated); (3) aligned (planar, destroyed, smoothed, levelled), as distinguished by Zapletal (1969), Demek (1984), Osipov, Gurov (2018) and Dávid (2010). Another view of montane landforms is represented by the classification according to their dimension (Dávid 2010) into macro-, meso- and micro-shapes. Although specific numbers are not unambiguously assigned to them, the dimensions can be designed as follows: megaforms (n.10 ha and more), macroforms (max. n.10 ha), intermediate formations (max. n. $10^{\circ} \mathrm{ha}$ ) and microforms (less than $1 \mathrm{ha}$ ). This whole range of forms of different sizes can be distinguished on a single object. Considerable attention is paid mainly to convex landforms, which in mining landscapes significantly shape the appearance of the territory. The most common are heaps: conical, ridge, terraced and plateau/flat (Zapletal 1969; Havrlant 1980; Demek 1984; Sütö 2010; Dávid 2010; Kirchner, Smolová, 2010). Slope heaps (Havrlant 1980; Kirchner, Smolová 2010), humped (Sütö 2010) and truncated cones (Zapletal 1969, Dávid 2010) are far less common. While heaps can reach a variety of sizes and are a manifestation of the industrial extraction of raw materials, artisanal extraction predominantly produces microforms. Examples are seen with spoil heaps after panning for metals and gems. Concave shapes often associate territorially and form heap complexes (Havrlant 1980) or spoil heap fields (Demek 1984).

Negative landforms are created both by mining raw material and by purposeful excavation or modification of objects for material storage, most often sludge decanter and wastewater retention. In solid rock, quarries or pits are formed by mining (stone), in loose rocks, gravel pits, sand pits or loam pits are formed according to the mined material (see Kirchner, Smolová 2010). Industrial ponds (mine ponds, for water retention for various purposes, in the case of placer directly for mining purposes) and sludge ponds (decanting plants, for sedimentation and storage of fine material from process water, which cannot be discharged directly into natural waters) are created spontaneously with later treatment or as planned water objects).

Aligned montane landforms are created both by removing the original ridge through gradual removal of mined material (e.g. by extracting small elevations of 
hard rocks in quarries, or sand dunes in sand pits) and filling natural depressions with deposits (in shallow basins and the ends of small valleys and ravines).

The resulting mining landforms are subject to the developmental cycle (Kirchner, Smolová 2010) or the geomorphological cycle of the mining landscape (Sütö 2010), when a new balance of the anthropogenic landform with local conditions is gradually established by exogenous factors. In this way, evolution stages of objects of a given type are created, from fresh through disturbed to decomposed ones. Erosion and denudation slope processes, pedogenesis and biota in the context of local moisture-temperature conditions contribute to the destruction of the original shape. While in the past various legislative measures recommended or directly required the removal of modern mountain reliefs by regenerating the "pre-mining" state, now there are increasing requirements for their integration into the current landscape by revitalization due to their undeniable environmental value (Dávid 2010) or as evidence of technical heritage in a post-industrial landscape (Kolejka, Klimánek 2012), and some of their parts can even develop spontaneously (Lednyev et al. 2020, Pešout, et al. 2021). So far, this issue has been addressed differently in different countries around the world. In principle, however, there is currently pressure everywhere to regenerate the affected areas, at least regarding recent mining forms of relief, especially if they are a source of environmental degradation (Kaidanova et al. 2018). In some places (often to the displeasure of local organizations and residents and some conservation circles) the old, stabilized forms from the time of industrial society are being removed. Nevertheless, large areas affected by mining still do not have the attention of the administration nor the public. The reason is usually the remoteness of such areas from settlement centres. These also include numerous localities in Siberia, some of which are famous for ancient and contemporary gold mining, especially the unmissable traces of placer gold mining.

\section{Study aims and research methodology}

At present, great attention is generally paid to the industrial and mining forms of anthropogenic relief in the scientific community. The forms created by industrial placer gold mining are not discussed in the professional literature practically at all, although it can be assumed that in the course of this form of gold mining huge volumes of material are being displaced, which undoubtedly involves the emergence of appropriate anthropogenic relief forms. The formation of such forms is related to the topography of the deposit location, the nature of the material transferred, the technology used to extract the raw material and the storage of processed rock, but also to the overall organization of work and the legislative environment of the country where gold is mined. The reasons for the entirely peripheral research position of these forms of relief may be: (1) it is an economically and environmentally 
sensitive topic associated with the possible lack of interest of miners in publicity; (2) localization of mining in usually remote areas with harsh natural conditions and poor accessibility; (3) limited possibilities of spending time in mining areas.

The main objective of this paper is to provide readers with interesting knowledge about specific anthropogenic landforms from one of the most important world gold mining areas, which is Eastern Siberia in Russia.

The specific research objectives are the following:

1. Presentation of the issue of industrial placer gold mining in Siberia in the world thematic context according to the literature review.

2. Acquisition of photographic, drawing and map documentation of selected typical examples of anthropogenic relief forms created during industrial placer gold mining in the research areas visited.

3. If possible, to explain the origin of selected forms and compare them with the results of analogous gold mining elsewhere in the world, and to assess the uniqueness of the landforms identified.

The research methods used were subordinated to the stated objectives:

1. Study of available literature on the topic (it should be noted that the author did not find any publications that focus on anthropogenic relief shapes associated with industrial (large-scale) placer gold mining.).

2. Carrying out field research in the visited gold-bearing fields in Siberia, associated with the acquisition of relevant documentation. Partial methods used included: taking photographs of relief forms, creating terrain sketches of studied forms, determining the dimensions of objects - a qualified estimate by comparison with the average height of persons and machines and measuring using the band meter, observing the process of genesis of observed forms where possible (the process was underway).

3. As part of the indoor research, the image material acquired in the field (photographs and sketches) was analyzed, the identified shapes were classified into types and a description of them was performed.

4. Visual interpretation of the published color satellite image (with ground resolution approx. $10 \mathrm{~m}$ ) on screen connected with the compilation of a detailed map of the surface of the selected visited gold-bearing field in ArcView GIS with the support of photographs taken in the field. Photographs and drawings of representative examples of landforms associated with local gold panning were taken in the mapped area. These are captured on a processed satellite image. Landforms of the same types were identified from the image on the basis of analogous visual expressions. The used color satellite image is published without further details (technical parameters) on the Mapy.cz server. Topographic maps at a scale of 1:200,000 were available for rough orientation in the field. 
5. Visual comparison of studied relief forms identified in Siberia with forms created during industrial placer gold mining elsewhere in the world. In fact, a comparison was made with the processes taking place in the Yukon Territory in Canada with generally similar natural conditions and documented quite exceptional literary sources (these are focused on the technological, economic and geological side of mining, but with a rich photographic accompaniment to identify related anthropogenic landforms).

Field research took place through a personal visit to the golden fields on the rivers Olchan, Inyali, Nera, Susuman, Pautovaya, Tuora-Tas and Ola. Field research could be carried out only where the author could travel by available means of transport, especially off-road vehicles with high throughput. Part of the studied localities is located within reach of the Yakutsk-Magadan highway, from which it was possible to reach the monitored landforms on foot.

The actual methodological procedure at the site included:

1. Searching for a representative specimen of a given type of anthropogenic landform.

2. Observation of the landform and identification of its characteristic parameters (overall appearance, possible microforms, size, estimation or measurement of its size).

3. Acquisition of a terrain sketch of the selected object at the optimal viewing angle to capture the characteristic appearance.

4. Taking photographs of the object(s), optimally also from several sides, in order to document the details of the surface and place it in a wider area.

5. Acquisition of photographs capturing the overall appearance of the studied gold-bearing field.

6. Wherever possible, the formation process of landforms was observed during mining or accompanying activities (moving and storing material, riverbed modifications, etc.).

7. After the end of the working day, the collected material was selected in order to preserve the documentation of representative forms of the relief.

The indoor part of the research took place both in the visited region (Republic of Sakha, Magadan Region) at the university workplace (internet workplace, personal office) and at the home workplace in Czechia (Masaryk University, Institute of Geonics AS CR).

Indoor research included:

1. Evaluation of collected field material and selection of representative images of identified anthropogenic landforms.

2. Searching for visual documentation from similar gold mining in a similar natural environment in available literary sources. 
3. Classification of detected shapes into known classifications (active, fresh and degraded shapes; convex, concave and planar shapes).

4. Creation of sample image documentation describing the identified specific anthropogenic landforms in the studied gold-bearing fields.

5. Visual interpretation of the satellite image covering one of the gold-bearing fields where the field survey was conducted. The mapping of the forms of the relief according to the given satellite image in this area was suitably based on the graphical documentation taken in the field. The result is an original map of anthropogenic landforms of a gold-bearing field studied in detail.

6. Compilation of text documentation for the research.

\section{Gold mining in Siberia}

Gold has been mined in Siberia since the Middle Ages (Nosovskiy, Fomenko 2015). It was often a surface collection. Industrial mining spread mainly in the early $20^{\text {th }}$ century in the Lena gold fields in the Patom Highlands on the border of the eastern edge of the present Irkutsk Kray (Region) and the Zabaykalsky Region near the town of Bodaybo on the River Vitim, a tributary of the Lena River. Mining was carried out there by the Russian-British company Lenzoloto (Lena Goldfields Ltd., originally a private company founded in Irkutsk in 1882). It became infamous in 1912, when it called in the army to suppress a workers' strike, killing several hundred strikers. Subsequent modernization using new machines from the USA was launched by an order in 1917, but before their delivery, the company was nationalized in 1918 (and then re-established in 1992).

The industrialization of the Soviet Union in the 1920s and 1930s was seen, among other things, in the purchase of modern technologies, especially from the USA, the UK, Czechoslovakia and Germany. The Soviet Union also paid with raw materials, mainly gold. The prospecting of gold deposits was thus one of the key tasks of the academic sphere. In the 1920s, the future academic geologist and geographer Vladimir Afanasyevich Obruchev became famous in this area. Mainly thanks to him, gold fields in North-eastern Siberia in the Indigirka and Kolyma river basins became well known. Their opening is traditionally associated with the forced labour of millions of political and criminal prisoners in the Gulag (Glavnoye Upravleniye Lagerey - Main Directory of Camps) camp network. Their importance increased even more during World War II and after, when it was necessary to cover the costs of supplies of weapons, vehicles, aircraft and especially rear equipment under the Lend-and-Lease Act of 1941 (von Fenstein 2009). These supplies, especially the armaments industry, which soon exceeded the production of Nazi Germany, kept Soviet transportation going. In total, the USSR received material worth 11.3 billion then US dollars (for comparison, Great 
Britain 31.4 billion, France 3.2 billion, China 1.6 billion, other states 2.6 billion, of which Czechoslovakia 0.6 billion). This huge loan was gradually repaid with many commodities, including gold, platinum, precious metals, etc. (Hart 2020).

The pressure to expand gold mining did not subside even after the victory over Nazi Germany and militaristic Japan. During the Cold War and the centrally controlled economy, large parts of the national budget for arms production, the armed forces and the repressive apparatus kept going. These measures caused an outflow of labour power from both industry and agriculture to socially inefficient sectors. The USSR became the world's largest food importer. Due to the deepening technological lag behind the world, it was necessary to purchase licenses for more progressive products. The number of these purchases that were paid for in gold can hardly be traced for the time being. However, the funds have had to be traced in the state's economy and it can be assumed that precious metals formed a significant item in them. The current Russia devotes extensive resources to the prospecting and mining of mineral wealth. Large volumes are exported with relatively little added value. Gold mining is widely supported by the state, but it faces a number of regulations and formal restrictions. Mining is controlled by several companies in the hands of Russian and some foreign owners (Farand 2018, Burges 2015). However, many other companies and individuals work in the field seasonally. In total, individuals collect approx. $250-300 \mathrm{~kg}$ of gold per year for obligatory purchase by the state, for example in the Magadan Region. Mining units with an area of 15 ha are leased for 5 years and are worked for about 3 months a year. Explosives are prohibited and the areas can only be dug to a depth of $5 \mathrm{~m}$. Foreigners are not allowed to participate in small-scale mining.

\section{Gold fields in North-eastern Siberia}

Eastern Siberia is the area east of the Yenisei up to the watershed of rivers flowing into the Pacific Ocean. In the current administrative division of Russia, Northeast Siberia is represented in the Far Eastern Federal District No. VIII by the Republic of Yakutia (Sakha). The other administrative units of this region belong to the traditional Far East region (see Brodko, ed. 2007). Historically, however, the whole region was considered part of Siberia. Gold fields are found mainly in Yakutia, the Magadan Region and the Chukotka Autonomous Okrug (Region), and only marginally in the Amur Region and in the Khabarovsk and Kamchatka Regions (Fig. 1). Their common feature is their position in complicated geological conditions (for deep and shallow deposits) and generally in their harsh environment for humans. The interaction of relief and atmosphere, land and ocean manifests itself in a special way here. A huge, high air pressure level builds up over the Lena, Yana, Indigirka and Kolyma river basins in the winter. The descending cold air cools the 


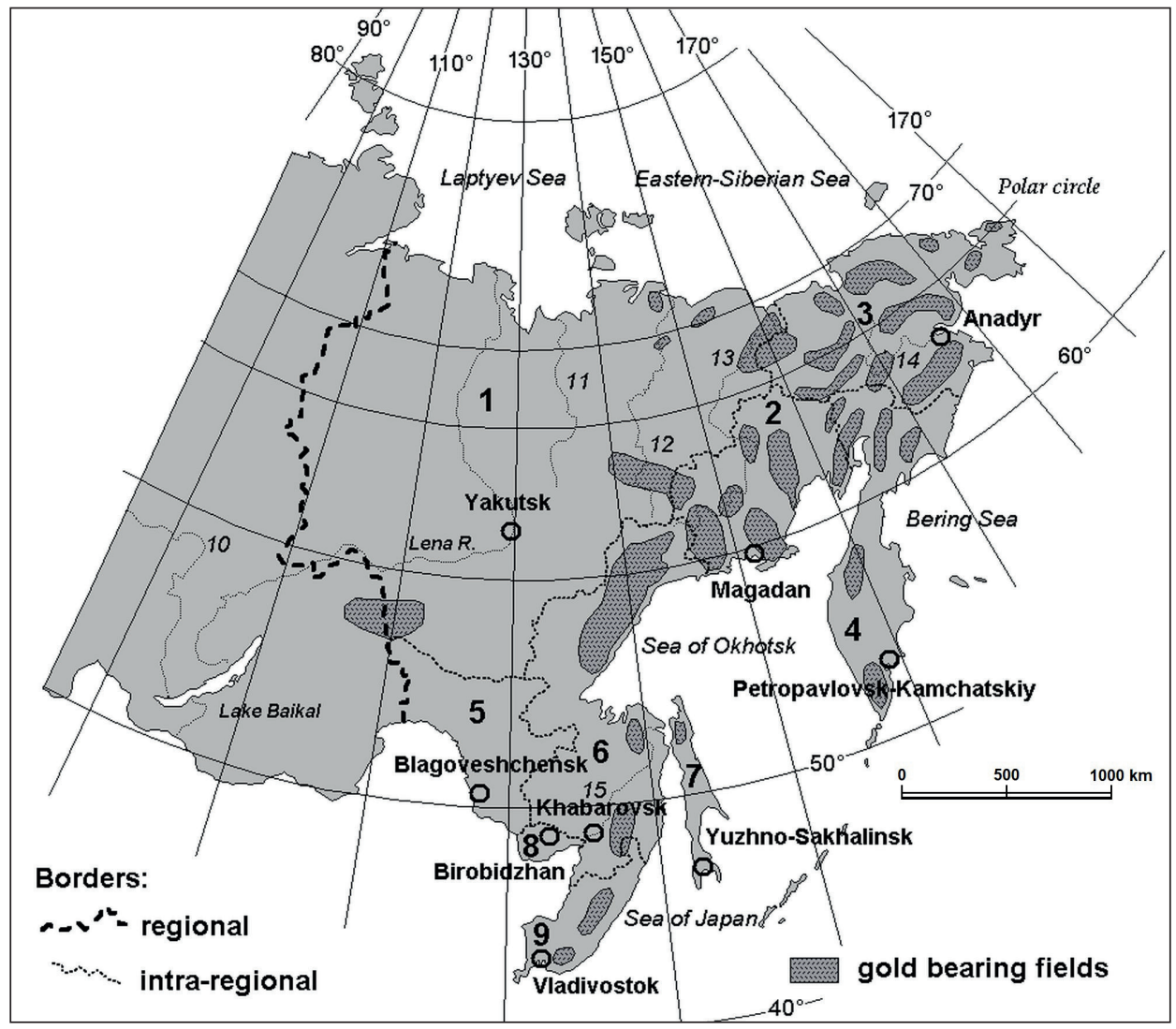

Fig. 1 - Gold-bearing fields in the Far East Region of the Russian Federation. Federal Units: 1 - Sakha Republic (Yakutia), 2 - Magadan Oblast, 3 - Chukotka National Okrug, 4 - Kamchatka Krai, 5 - Amur Oblast, 6 - Khabarovsk Krai, 7 - Sakhalin Oblast, 8 - Jewish Autonomous Oblast, 9 - Primorsky Krai; Rivers: 10 - Angara, 11 - Yana, 12 - Indigirka, 13 - Kolyma, 14 - Anadyr, 15 - Amur. Source: own processing based on set of maps.

deep valleys and especially the elevated inter-mountain basins and basins under intense radiation under a cloudless sky by nights. The average January temperatures with low snow cover (around $10 \mathrm{~cm}$ ) drop to $-50^{\circ} \mathrm{C}$ and below while in the surrounding mountains it can be up to $15^{\circ} \mathrm{C}$ warmer. On the shores of the Arctic Ocean, it is on average up to $20^{\circ} \mathrm{C}$ warmer in January; in a narrow strip along the Sea of Okhotsk about it is $30-35^{\circ} \mathrm{C}$ warmer. These conditions mean a thick layer of permafrost is maintained (sometimes up to $1,600 \mathrm{~m}$ ); the active layer with seasonal melting of soil ice thus reaches a few metres (1-3 m), and only during humid rainy years. Permafrost acts as an impermeable ground. Even relatively low summer cyclonic and storm rainfall (400-500 mm per year, most in summer) thus drains 

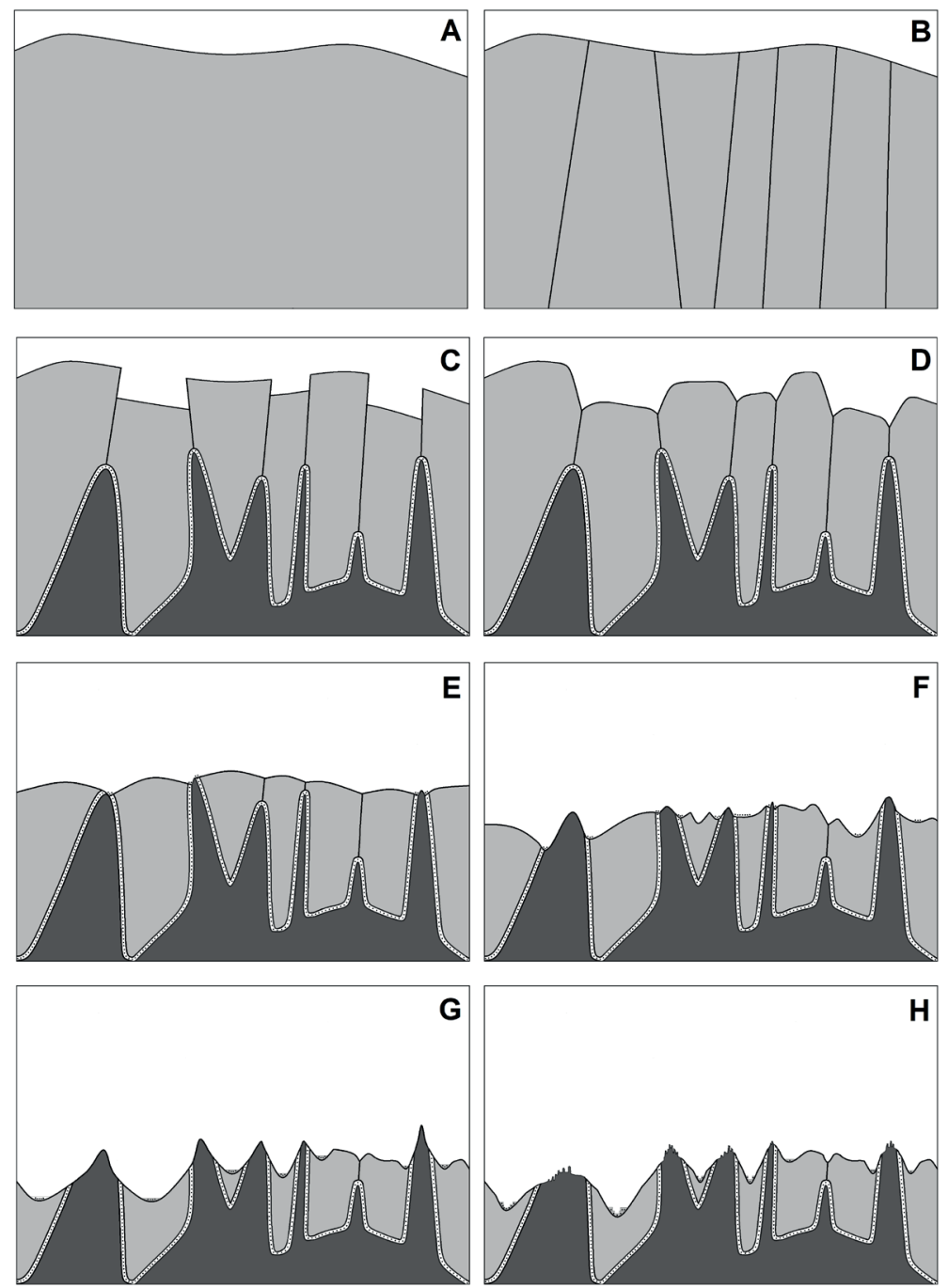

Fig. 2 - Model of genesis of primary and secondary gold deposits in the Upper Indigirka and Kolyma river basins. A - smoothed Cretaceous surface on Paleozoic shales; B - tectonic disruption of the Earth's crust at the beginning of the Paleogene; $\mathrm{C}$ - differentiated vertical shift of the Earth crust blocks with magma intrusion into faults and mineralization (metalogenesis) zone formation at the contact of shales and magmatic bodies; D - tectonic and erosion rejuvenated relief with primary gold deposits in the zone of mineralization; $\mathrm{E}$ - gently undulated relief as a product of intensive denudation, exhumation of ore seams leads to gold deposits "in situ" in weathering products; F - rejuvenation of the relief by selective erosion with the formation of "in situ" deposits and secondary sedimentary deposits; G - selective erosion-exposed resistant igneous formations with the removal of "in situ" deposits and formation of sedimentary gold deposits; $\mathrm{H}$ - frost weathering and cryoplanation led to development of tors (kyzylyakhs) on tops of magmatic bodies and to the repeated formation of secondary sedimentary gold deposits in floodplain sediments and river terraces. Source: own processing. 
off the surface or accumulates in depressions and in relatively warm weather (with air temperatures well above $+30^{\circ} \mathrm{C}$ ) it promotes the formation of mosquito clouds and other insects, often in still air.

Harsh environmental conditions make it difficult for gold bearings to become accessible. With the exception of the main road Yakutsk-Magadan (which includes segments, especially in the Magadan Region, keeping world standards) and several branches, or parallel branches, land transport takes place on partially paved roads, locally on a soil surface, and on riverbeds, especially with heavy trucks (fuels, supplies, machinery, building materials), or off-road trucks of the Ural type. Watercourses have bridges in only a few places, and they usually cross modified fords to a depth of up to about 1.0-1.5 m. The working season varies from place to place depending on availability and lasts for a maximum of May to September, but usually only for 3 months.

Active deposits are traditionally of two types: primary at the sites of mineralization, and secondary at the sites of accumulation of transferred gold corns (Fig. 2). Typical examples of primary deposits are represented by mineralization at the points of contact of young intrusions with older rocks, most often of Mesozoic age (Triassic, Cretaceous), and only locally of Palaeozoic (Permian) or Precambrian age (Aldan shield). Due to the fact that igneous rocks are more resistant to weathering than older shales, the areas of mineralization were exposed by selective weathering and chipped away; weathering of contact zones in gold-containing seams led to material relocation and deposition in relatively close proximity to the source. It was later reactivated and transferred downstream again. Original magmatic intrusions were exposed and highlighted. Rock groups of the tors type, locally called kyzylyakh, were then formed by frost weathering. To some extent these are indicators of both primary and secondary gold deposits in the neighbourhood.

\section{Selected anthropogenic landforms originated during industrial placer gold mining in North-eastern Siberia}

The author of this paper had the opportunity to visit the gold fields in Northeastern Yakutia and in the Magadan Region of Russia repeatedly between 2010 and 2018. The field research took a total of about 5 weeks and the author carried it out as an official foreign member of international student research expeditions organized by the North-Eastern Federal University in Yakutsk. The starting point was the town of Ust-Nera on the Indigirka River and the area of interest extended north to the Inyali River in the Cherski Mountains, south to Oymyakon. The western edge coincided with the foothills of the Verkhoyansk Mountains in relation to the Yakut Plateau and the eastern edge with the coast of the Sea of Okhotsk in the wider vicinity of the City of Magadan. The observations mostly focused on mining 


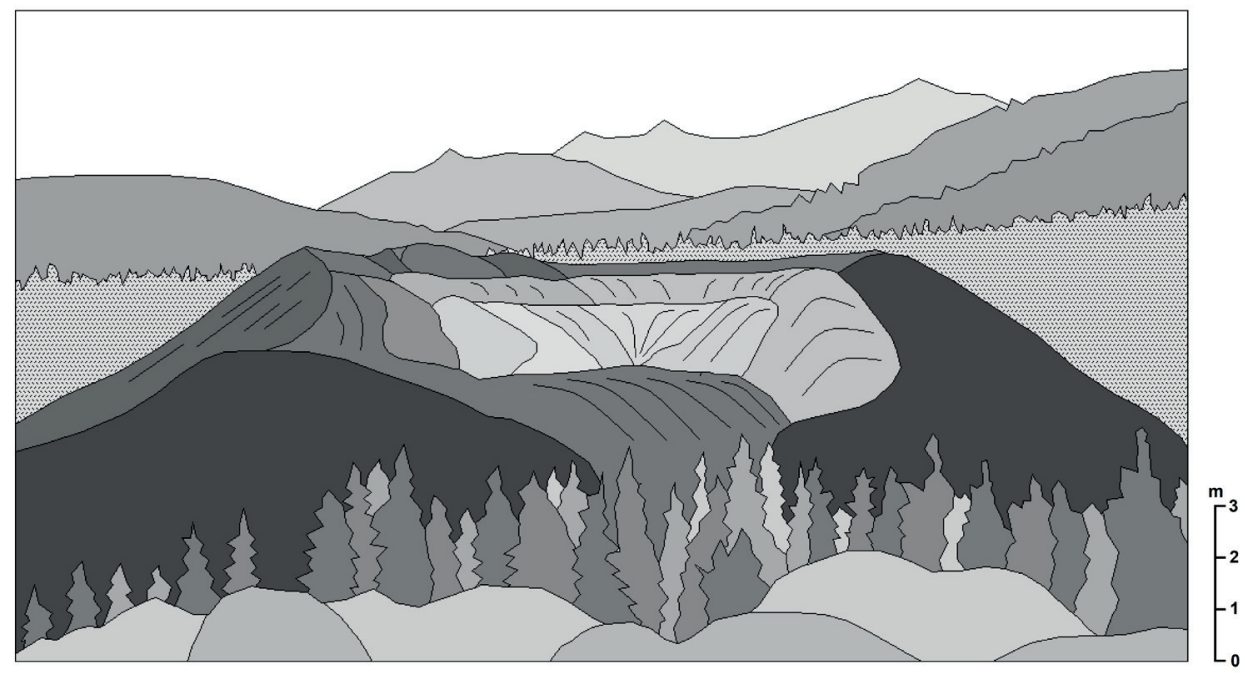

Fig. 3 - "Stepped half-craters", or semi-arched heaps with a stepped slope arrangement on the inside of the arch. Because of the perspective character of a drawing, the approximate scale is applicable in the central position of the front part of the object only, applicable also in Figures $4,5,6,7,8$ and 9. Source: own processing based on own photography.

sites in river valleys in the upper parts of the Indigirka and Kolyma river basins. Just the visited areas with the remains of placer gold and the areas of its recent mining occupy several tens of square kms with a huge number of anthropogenic landforms.

By far the most numerous remnants and at the same time a manifestation of active industrial placer gold mining are terraced semi-arched heaps ("stepped half-craters") with a stepped/terraced slope arrangement on the inside of the arch (Fig. 3). The range of these arcs generally varies between $80^{\circ}$ and $210^{\circ}$. Most often it is around $1 / 3$ of a circle. The heights of the steps vary between 2 and 5 metres and the width is similar. The vast majority are arches open to the southern sector. The placer machine - wash-plant - is placed on a gradually increasing arch top. Gold-bearing material is transported into it from the outside. The working water is pumped from the nearest water reservoir (usually excavated pits filled from the aquifer in the alluvium of the river) and is fed through the pipeline from the convenient side. The washed material goes under the machine, from where it is poured around the conveyors until it forms a stepped arcuate wall. The used sludge water flows out of the arch due to gravity and the sludge settles in excavated or fenced tanks. It is forbidden to discharge turbid water directly into a watercourse or other natural water object. Relatively large fields of these landforms, existing in various stages of genesis and destruction, originate in this way. In the immediate vicinity of the wash-plant, there is a mining pit for the raw 


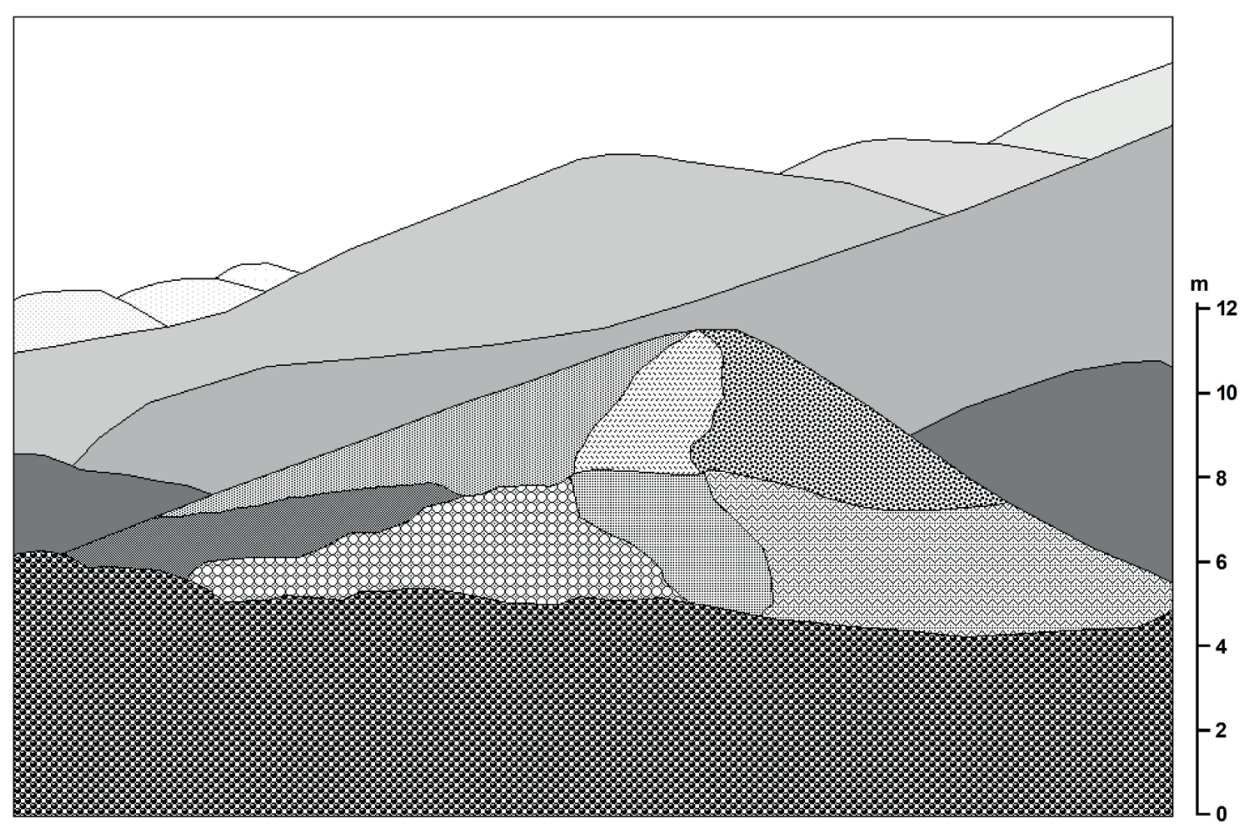

Fig. 4 - Pointed asymmetric cone. Source: own processing based on own photography.

material. This will eventually become a sludge tank. Thus, around the stepped arched heaps ("stepped half-craters"), a very varied relief is created in the originally flat floodplain. Reclamation can then occur only after a long period of time through planation of the heaps and filling up the depressions. By comparison, wash plants also operate on gold fields in the Yukon, Canada, but there are washed sands from a machine dump located essentially at the level of the surrounding terrain scattered into pointed cones using the stacked tailings that levelled after the season (van Loon 2019). Washed sands are also loaded onto vehicles with conveyors and transported to the storage, or directly levelled to the final terrain (Bond, van Loon 2017). Semi-arched heaps occur in the gold-bearing fields of Siberia in various sizes (with a height of several metres to a maximum of about $25 \mathrm{~m}$ ), but they were not observed in the Yukon.

Heaps in the form of cones, either pointed (Fig. 4) or truncated (Fig. 5), occur significantly less. Pointed cones are formed by pouring tailings on long conveyor belts. These are unlike the Klondike in the Yukon, Canada (van Loon 2019). In Siberia, there is plenty of space available on usually wide valley bottoms in midmountain conditions, which the mountain conditions of the Rocky Mountains do not offer, so the cones are low, with slightly inclined slopes and many of them are also formed by bulldozers from below. Truncated cones are formed through loading from trucks from above. The loading route has a very slight gradient, 


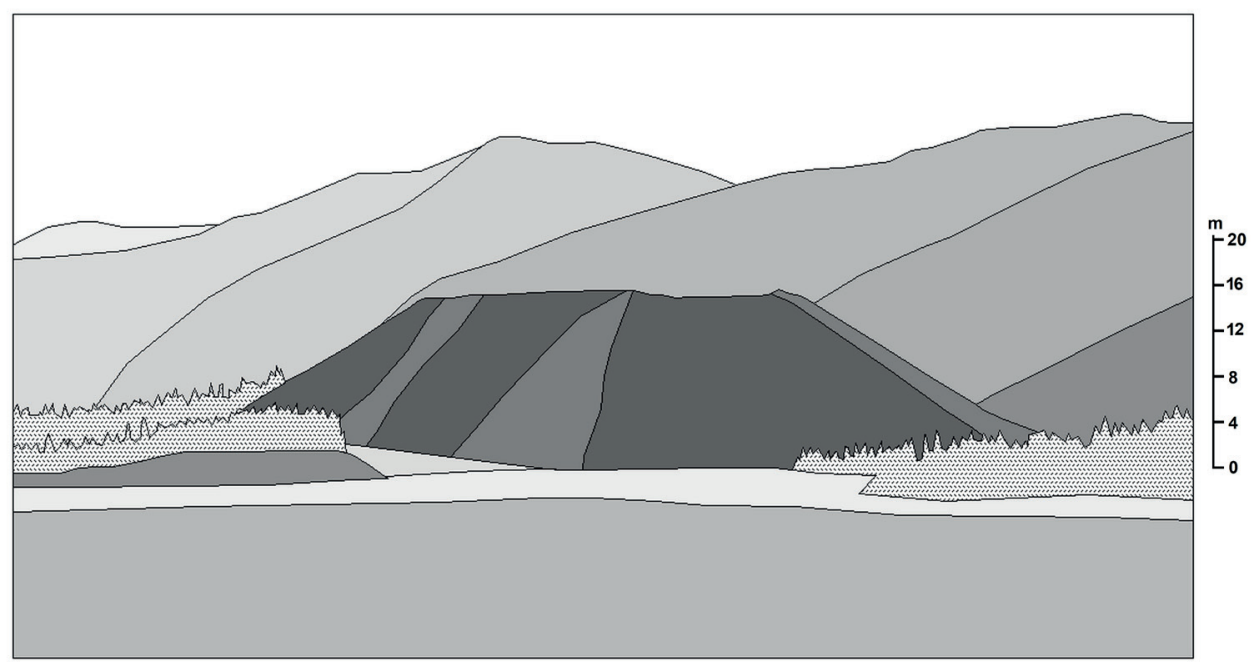

Fig. 5 - Truncated cone. Source: own processing based on own photography.

so that the cone is asymmetrical in terms of inclination. It is common for these truncated asymmetrical cones to "turn" into table heaps. This applies especially to landforms from older periods, when modern panning machines were not available and streams of water were flowing into wooden troughs, where excavators, loaders or dumpers poured material for washing, were more often used to wash the pay gravel. This procedure was simpler and cheaper, but the efficiency was lower. In many cases, these heaps are mined and washed again. Many of them are overgrown with forest. In the places where gold-bearing material is found, a chaotic relief of convex and concave landforms is created on the valley bottoms, while artificial elevations of all types give the landscape its character. The pointed cones are less represented in Siberia; they are usually low (only 5-15 m), in contrast to the cones formed during coal mining, and the originally sharp shapes are soon disturbed by natural processes. On the contrary, table heaps reach considerable sizes (up to several hectares at heights up to $15 \mathrm{~m}$ ). The higher and sharper pointed cones are cleared in the Yukon soon after mining.

In narrow sloping valleys in higher (mountain) terrain (not only), industrial spoil heap fields are created (Fig. 6). They consist of ramparts of washed and unsorted material poured perpendicular to the valley axis. The water flow is thus pushed out to one edge of the valley floor. The loading of the ramparts proceeds from the upper part of the valley. The slope of the rampart down the valley is steep whereas the slope of the rampart up the valley is gentler and is created by the accumulation of washed material by machines. The machines access these sloping terraced steps at the other edge of the valley. The raw material is mined 


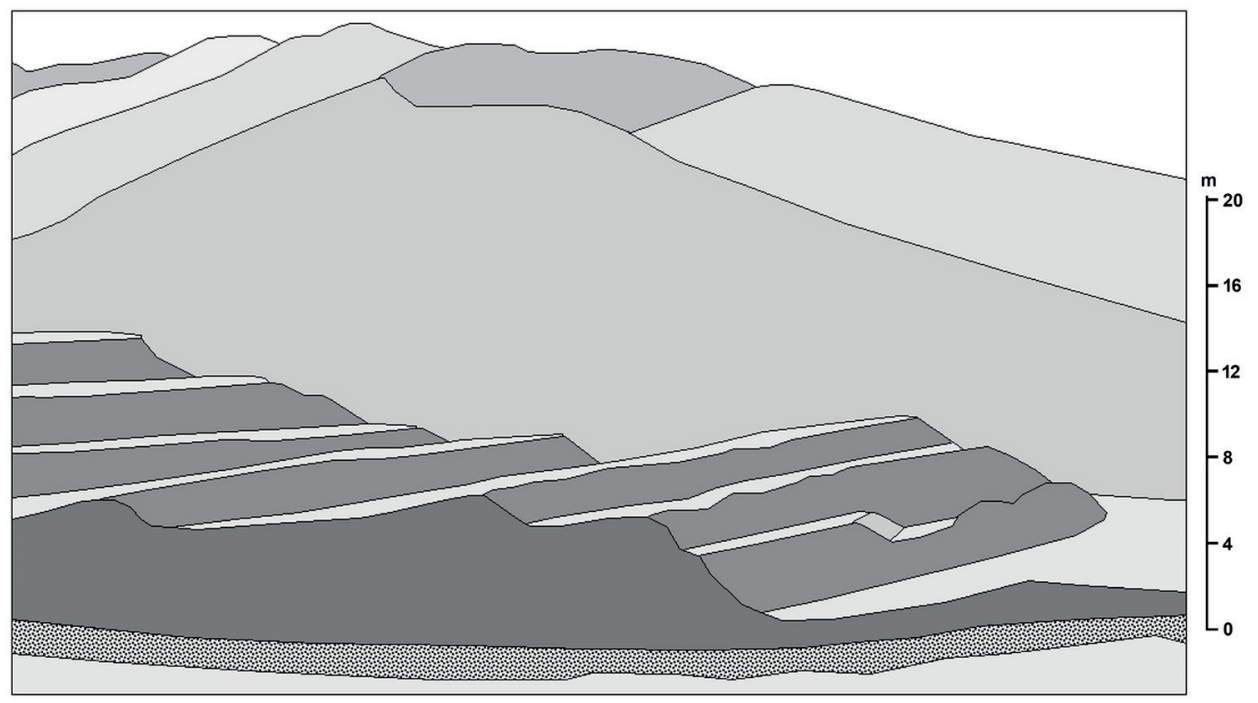

Fig. 6 - Industrial spoil heap field in a narrow mountain valley. Source: own processing based on own photography.

by retreating up the slope of the valley. Parallel rampart-like dykes of industrial spoil heap fields also cover artificial gentle slopes in/over alluvium (see Fig. 10). Industrial spoil heap fields divided into low parallel ridges cover large areas in Siberia, especially in wide floodplains (up to several hectares at altitudes up to $15 \mathrm{~m}$ ). They do not occur in the Yukon.

The negative landforms created during industrial placer gold mining in the studied areas in Siberia are basically of four types. Mining pits are directly related to mining, usually with an irregular floor plan, depending on how the gold-bearing sediment is removed in the leased area (claim). The bottom of the pits is above the groundwater level in the talik of the floodplain. In Canada, mining extends below this level using floating dredgers (Bond, van Loon 2016). If mining takes place in permafrost, the mining pit resembles a pit quarry with vertical edge walls (Fig. 7). Due to the action of warm air, the material melts and falls off at the foot of the walls, from where it is taken by the loader and transported to the wash-plant. In the gold fields of the Yukon, the process of melting frozen ground is accelerated by washing with water from nearby water sources (Bond, van Loon 2017). These landforms are abundant in Siberia and differ from similar shapes in the Yukon, usually with a straight wide front due to their formation at the edges of wide valleys.

Water for panning is most often pumped from a small round (although this is not a condition) pit with a surface hydraulically connected to the groundwater level, or from excavated basins occupying the lowest position in the mined area (e.g. above 


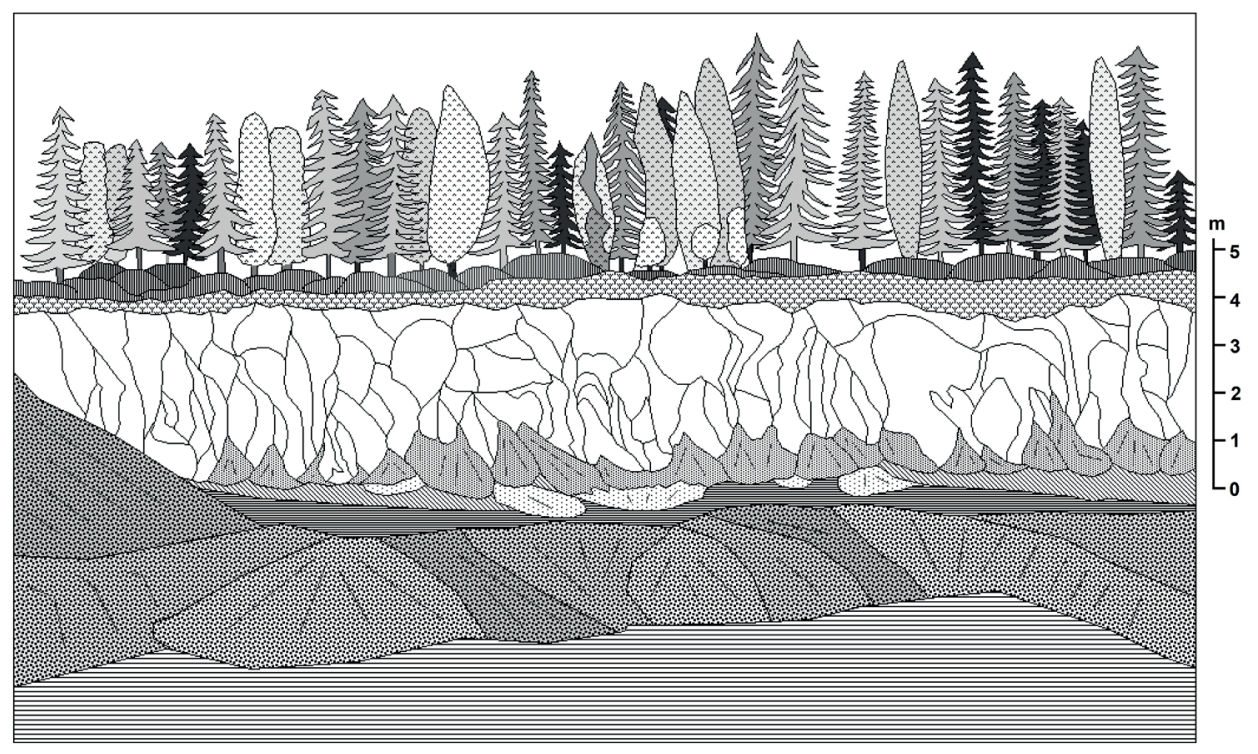

Fig. 7 - Mining pit in permafrost with vertical edge walls. Source: own processing based on own photography.

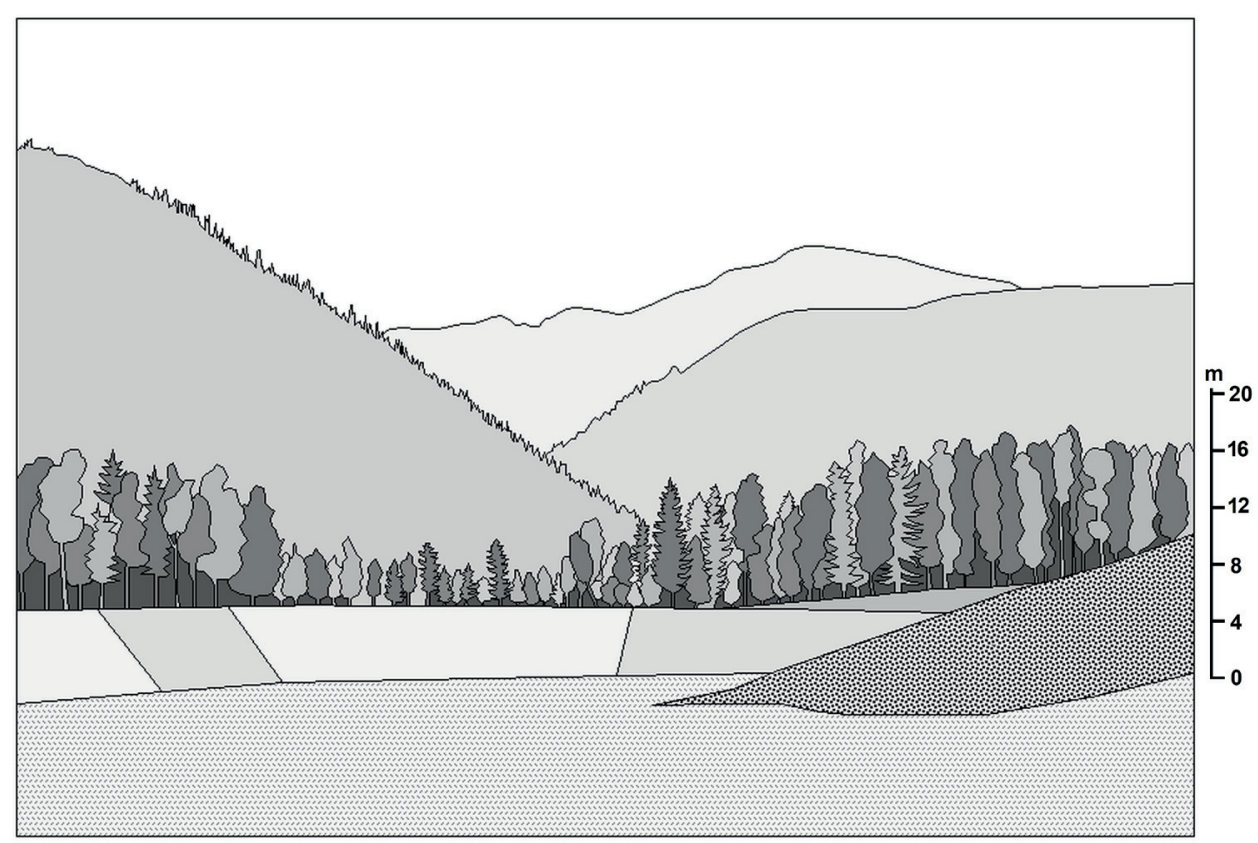

Fig. 8 - A regularly designed mining pit in the newly mined deposit. Source: own processing based on own photography. 


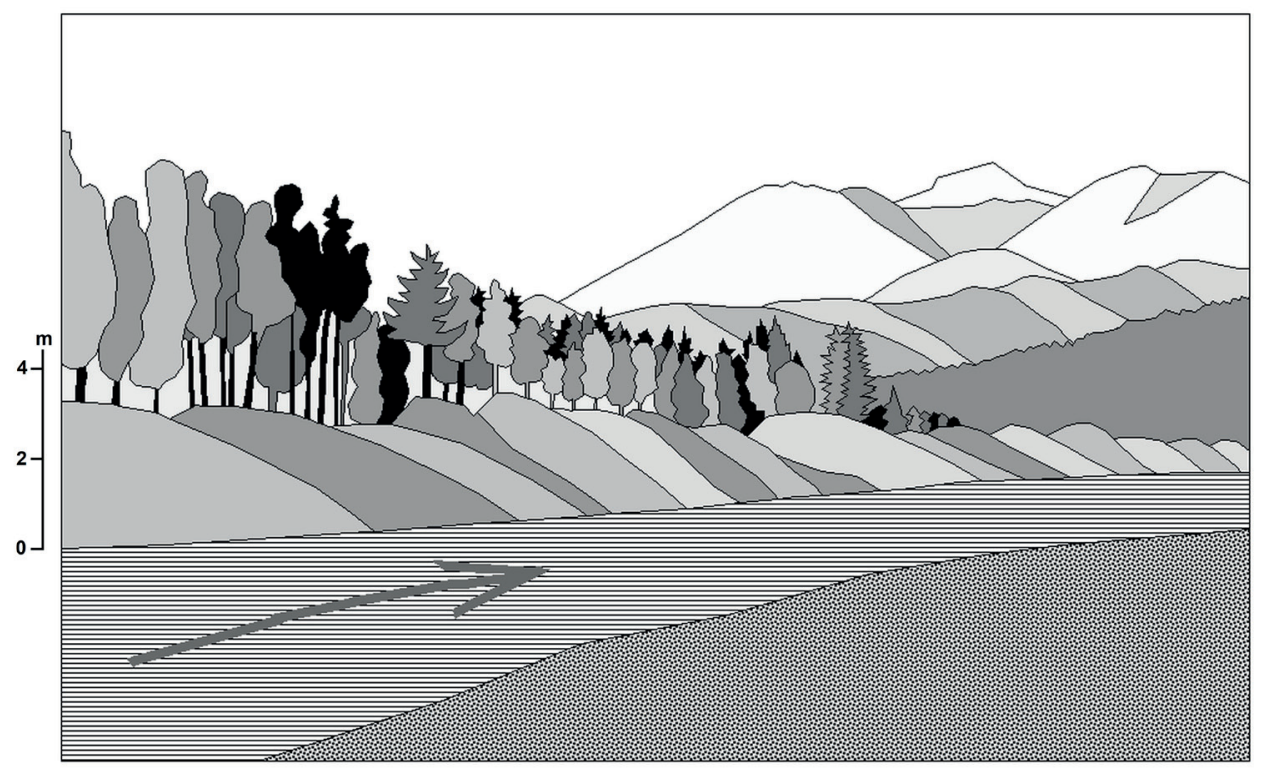

Fig. 9 - Artificial riverbed with a dam on the opposite bank. Source: own processing based on own photography.

the permafrost). In both cases, there are many places where gold-bearing sediment has already been mined. Rarely are these water sources deeper than $1.5 \mathrm{~m}$. If these sources are active, a pump is located on an elevated spot above the deeper water. Sludge tanks are artificially constructed in the elevated position above the groundwater level. These are often additionally modified mining pits on a permeable ground, so that the material of the bottom and slopes allows the filtration of turbid water and its outflow into the surroundings. It is a fact that sludge tanks accompany newly opened mining pits (Fig. 8). Their construction is a condition for the approval of mining by the environmental protection authority. Previously, turbid water was discharged anywhere, but in some places the protection of fish in streams was respected and the water was at least temporarily retained in the excavated pits, from where it leaked or overflowed into the stream, depending on the inflow. Extensive excavated areas (continuous areas up to tens of hectares) are usually left to their fate in Siberia, including newly created lakes. In the Yukon, mining pits are loaded with tailings during mining. The last significant landforms associated with mining are already indirect - they are artificial riverbeds (Fig. 9). They served to divert the flow from the active mining area, to protect it from large amounts of water, but usually to reduce the groundwater level, so that the collection of gold-bearing material could take place using conventional techniques from the greatest possible depth. In this way, the riverbeds of important and water-rich streams were modified, such as the Nera River and Olchan River - tributaries of 
the upper Indigirka course - up to several kilometres long. The new riverbeds in Siberia are left to spontaneous development. In the Yukon, there is a clear effort to restore the terrain to its original condition before mining.

\section{Discussion}

The different use of mining technology in Siberia compared to the Yukon, as well as the different management of deposits after the end of panning, has led both to the emergence of completely or partially different montane shapes of anthropogenic relief as well as to different futures. This applies especially to recent forms whose genesis is active or has recently ended. In Siberia, like elsewhere in Russia, relatively strict laws apply to the management of the site after mining closure. Miners are obliged to regenerate the area. This, of course, applies to current active mining. However, large areas are affected by mining taking place in the period before the enforcement of the relevant environmental laws. There, it will be very difficult to enforce reclamation if it is a matter of clearing traces of mining activities. A rough estimate in the upper Indigirka and Kolyma river basins will be hundreds of square kilometres of heap complexes and mining pits (Fig. 10), where mining has taken place in various forms since 1934. The eradication of mining traces is practically out of the question and seems counterproductive in many respects. There are two groups of reasons for leaving abandoned areas to spontaneous development. On the one hand it is a new type of environment with significantly higher geodiversity (and subsequently biodiversity) than the original far less rugged and diverse valley floor, while on the other hand it is a remarkable type of natural and technical heritage that is worth preserving or at least spontaneously including in local "cultural" landscapes. In Canada and Alaska, many previous areas of gold mining are still of public interest and are tourist destinations. Given that part of the former and current gold-bearing fields were quite accessible by relatively high-quality roads, a similar perspective can be considered in Siberia.

From a professional point of view, it can be stated that the spatial distribution of anthropogenic landforms on the gold fields of Siberia and the Yukon is completely chaotic, as it resulted from the needs of mining. From the available literature describing the site in the Yukon, it can be deduced that the local landforms (convex and concave, terrestrial and water) are more numerous in number, and smaller in area and volume than in Siberia, which means a more diverse post-industrial landscape, but with less visual impact on potential observers (if they do not have the opportunity to observe the landscape from above). Their typological diversity is also smaller - after small mining, table heaps, residual pits with water, horseshoe-shaped dikes with a water pit in the middle, pointed cones and ridges 


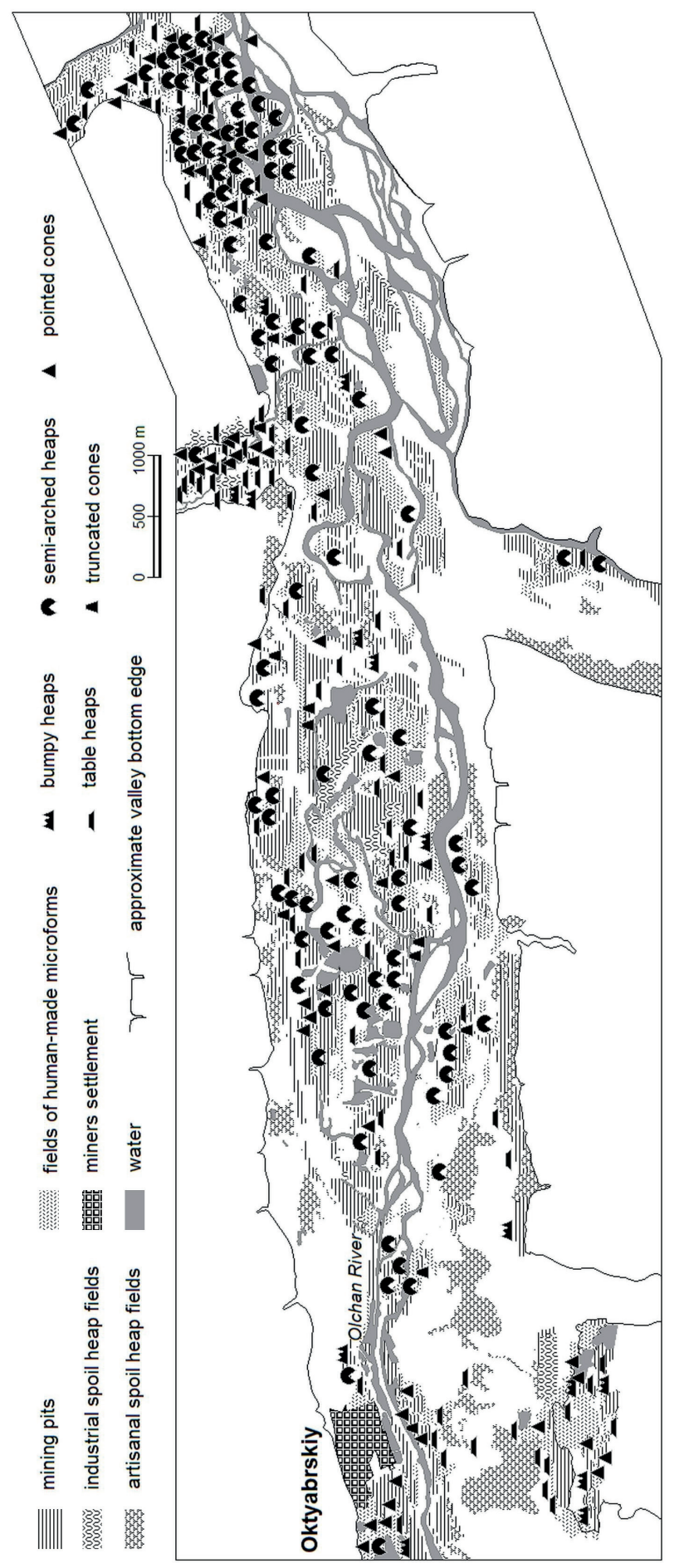

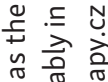

है $\stackrel{\pi}{0} \sum^{\pi}$

은 등

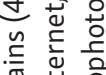

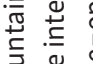

을

중

जับ

บ

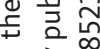

. $\frac{\pi}{2} \stackrel{\infty}{ก}$

ช

.

으

亲

पัํㅡํำ

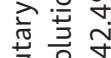

긍워 긍

‡

룬

$\geq \pm N$

든 건

敢

О 들

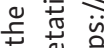

능흔

춸 过

范

๑

ㄷำ

넝

잉ㅇㅇ

는

ป ह

등 휴 항

o $\begin{aligned} & 1 \\ & 0\end{aligned}$

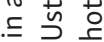

$\times 4$ 范

늘

언 호

융ㅎㅀ

드음

1 站

눈 方 
with an irregular circumference predominate (van Loon 2019). In the visited Siberian gold fields, large-scale landforms predominate, significantly exceeding their surroundings, while the negative landforms represent artificial lakes of various shapes and sizes. Among them are relatively large flat table heaps from older placer periods. Terraced semi-arched heaps ("stepped half-craters"), which are visually very varied in relief, significantly predominate. Most of them are fresh shapes without vegetation cover, but the beginning of aging is also observable on them and is accompanied by erosion of exposed top arches, edges of inner terraces and disruption of longer outer slopes.

Overgrowth of vegetation (birches, larch trees) begins from below, usually from the banks of artificial water bodies.

In the future, it is also possible to anticipate a change in the relatively extensive modifications of watercourses, in the sense of their gradual clogging of sediments and the return of meanders, islands and gravel benches. Thus, other human-made landforms within the reach of watercourses could be completely or partially removed. Similar semi-natural processes occur to a limited extent in the Yukon deposits, as new artificial forms are usually technically smoothed out after the season (Bond, van Loon 2018) and only in an abandoned area can the effect of regulated water flow apply gradually (so as not to endanger mining in the neighbourhood in the following season).

\section{Conclusion}

In Siberia, industrial (large-scale) placer gold mining affected about $2 / 3$ of the duration of the $20^{\text {th }}$ century and continues to this day. It has always relied on sufficient human labour, but was often forced to function without personal interest in the quality of the work performed. Some mechanization and systematization of work was needed from the beginning due to the mass commitment of the workers. The later release of human labour from the 1960s was accompanied by increasingly sophisticated and efficient mechanization (in some places the already washed-out deposits were re-mined). Despite the relatively short period of mining, the massive deployment of people and later machines led to the remodelling of the relief of large areas of floodplains and valley floors with small and large watercourses. Undoubtedly, a large part of them will become a permanent testimony to the extensive terrain building human activity in the harsh natural environment, and in Siberia also a reminder of slave labour in times of lack of political freedom, as well as technological progress. Research into these areas in terms of natural and human sciences is only beginning to develop intensively. The presented paper thus offers the results of one of the first studies of the relief of gold-bearing fields of Siberia. 


\section{References}

ADDY, S.N. (1998): Ghana: Revival of the mineral sector. Resources Policy, 24, 4, 229-239.

ARYEE, B.N.A., NTIBERY, B.K., ATORKUI, E. (2003): Trends in the small-scale mining of precious minerals in Ghana: a perspective on its environmental impact. Journal of Cleaner Production. 11, 2, 131-140.

ASNER, G.P., LLACTAYO, W., TUPAYACHI, R., LUNA, E.R. (2013): Elevated rates of gold mining in the Amazon revealed through high-resolution monitoring. Proceedings of the National Academy of Sciences of the USA, 110, 46, 18454-18459.

BOND, J., VAN LOON, S. (2016): Yukon Placer Mining 2015 Exploration and Development Overview. In: MacFarlane, K.E., Nordling, M.G. (eds.): Yukon Exploration and Geology Overview 2015, Yukon Geological Survey, Whitehorse, Yukon, 47-57.

BOND, J., VAN LOON, S. (2018): Yukon Placer Mining 2017 Development Overview. In: MacFarlane, K.E. (ed.): Yukon Exploration and Geology Overview 2017, Yukon Geological Survey, Whitehorse, Yukon, 19-32.

BOND, J., VAN LOON, S. (2017): Yukon Placer Mining 2016 Development Overview. In: MacFarlane, K.E. (ed.): Yukon Exploration and Geology Overview 2016, Yukon Geological Survey, Whitehorse, Yukon, 21-33.

BRODKO, A.B., ed. (2007): Национальный атлас России в четырех томах. Том 2. Природа, экология. Министерство транспорта Российской федерации, Федеральное агентство геодезии и картографии, Москва.

BURGES, A. (2015): Stunning Photos of a Siberian Gold Mine Only Accessible by Air-Or Ice Road, https://www.atlasobscura.com/articles/stunning-photos-of-a-siberian-gold-mineonly-accessible-by-air-or-ice-road (10.12.2020).

CASSELMAN, S., ed. (2018): Yukon Mineral Deposits Summary 2018. Yukon Geological Survey, Whitehorse, Yukon.

DÁVID, L. (2010): Quarrying and Other Minerals. Chapter 9. In: Szabó, J., Dávid, L., Lóczy, D. (eds.): Anthropogenic Geomorphology. A Guide to Man-Made landforms, Springer, Dordrecht, Heidelberg, London, New York, 113-130.

DEMEK, J. (1984): Obecná geomorfologie III. Univerzita J. E. Purkyně v Brně, Fakulta př́rodovědecká, SPN, Praha.

ENGLEHARDT, P.O., WARD, B.C., BOND, J.D., COLEMAN, M.J. (2015): Early Pleistocene glaciation and implications for placer gold deposits in Back Creek, Mount Nansen area, Yukon. In: Yukon Exploration and Geology 2015, Yukon Geological Survey, Whitehorse, Yukon, 111-129.

FARAND, CH. (2018): The Russian Magnate, 'Goldfinger' and Ex-Army Chief Discussing Siberian Gold Mine Deals With Arron Banks, https://www.desmog.co.uk/2018/06/13/russian-magnategoldfinger-and-ex-army-chief-discussing-siberian-gold-mine-deals-arron-banks (11.12. 2020).

GARSIDE, M. (2021): Gold production sorted by major countries 2010-2020. Statista, https:// www.statista.com/statistics/264628/world-mine-production-of-gold/ (12.1.2021).

GOLUBOVA, A. (2017): Global Warming Uncovers Biggest Canadian Gold Deposit. Kitco News, https://www.kitco.com/news/2017-10-17/Global-Warming-Uncovers-Biggest-CanadianGold-Deposit.html (15. 4. 2021).

GRÄTZ, T. (2003): Gold-mining and risk management: A case study from Northern Benin, Ethnos, 68, 2, 192-208.

GROVE, T. (2017): Siberian Gold Find Brightens Ruble's Future. The Wall Street Journal, https:// www.wsj.com/articles/russias-new-shield-from-u-s-sanctions-a-siberian-gold-mine11549535400 ?mod=searchresults\&page $=1 \&$ pos $=1$ (7. 3. 2021). 
HART, L. (2020): Dějiny druhé světové války 1939-1945. Jota s. r. o., Brno.

HAVRLANT, M. (1980): Antropogenní formy reliéfu a životní prostředí v ostravské průmyslové oblasti. Spisy Pedagogické fakulty v Ostravě, 43, SPN, Praha.

ILLE, E. (2019): International Joint Ventures in Industrial Gold Mining, Corporate Social Responsibility, and Harm-Production in Sudan. Africa Spectrum, 53, 3, 33-64.

KAIDANOVA, O.V., ZAMOTAEV, I.V., SUSLOVA, S.B., SHILKROT, G.S. (2018): Геохимическая трансформация ландшафтов Железногорского промышленного ареала (Курская область). Известия РАН. Серия географическая, 82, 3, 91-104.

KIRCHNER, K., SMOLOVÁ, I. (2010): Základy antropogenní geomorfologie. Univerzita Palackého v Olomouci, Př́rodovědecká fakulta, Olomouc.

KOLEJKA, J., KLIMÁNEK, M. (2012): Vymezeni a typologie postindustriální krajiny Česka. Geografie, 117, 3, 289-307.

LUNING, S. (2008): Liberalisation of the Gold Mining Sector in Burkina Faso. Review of African Political Economy. 35, 117, 387-401.

LACY, H. (2019): Mine landforms in Western Australia from dump to landform design: review, reflect and a future direction, In: Fourie, A.B., Tibbett, M. (eds): Proceedings of the $13^{\text {th }}$ International Conference on Mine Closure, Australian Centre for Geomechanics, Perth, 371-384.

LEDNYEV, S.A., SHARAPOVA, A.V., SEMENKOV, I.N., KOROLEVA, T.V. (2020): Растительные сукцессии на отвалах угольных шахт в лесостепи Тульской области. Известия РАН. Серия географическая, 84, 2, 239-245.

MACHÁČEK, K. (2018): Environmentální aspekty artisanální těžby nerostných surovin v oblasti východoafrických velkých jezer. Disertační práce. Univerzita Palackého v Olomouci, Př́rodovědecká fakulta, katedra rozvojových a environmentálních studií, Olomouc.

MACHÁČEK, J. (2019): Typology of Environmental Impacts of Artisanal and Small-Scale Mining in African Great Lakes Region. 11, 11, 3027-3051.

NOSOVSKIY, G.V., FOMENKO, A.T. (2015): Как было на самом деле. Бог войны. Издательство ACT, Moskva.

OSIPOV, S.V., GUROV, A.A. (2018): Классификация географических фаций горнопромышленных территорий (на основе исследований в Дальневосточном регионе). Известия РАН. Серия географическая, 82, 5, 91-103.

PEŠOUT, P., PORTEŠ, M., ČERNÝ PIXOVÁ, K., HENDRYCHOVÁ, M., KŘÍŽ, P., LACINA, D. (2021): Ekologická obnova hnědouhelných velkolomů. Ochrana přírody, 76, 2, 16-21.

SÜTÖ, L. (2010): Mining: Extraction of Fossil Fuels. Chapter 10. In: Szabó J., Dávid L., Lóczy, D. (eds.): Anthropogenic Geomorphology. A Guide to Man-Made landforms, Springer, Dordrecht-Heidelberg-London-New York, 131-154.

VAN LOON, S. (2019): Analyzing historic drilling data to investigate gold distribution on lower Hunker Creek and Klondike River. In: MacFarlane, K.E. (ed.): Yukon Exploration and Geology 2018, Yukon Geological Survey, Whitehorse, Yukon, 111-126.

VON FENSTEIN, P. (2009): Ekonomická situace SSSR v průběhu 1941-42 a spojenecká pomoc Lend-Lease. Díl 3, https://www.valka.cz/13348-Ekonomicka-situace-SSSR-v-prubehu-1941-42-a-spojenecka-pomoc-Lend-Lease-dil-3- (11.12.2020).

ZAPLETAL, L. (1969): Úvod do antropogenní geomorfologie I. Univerzita Palackého v Olomouci, Fakulta př́rodovědecká, Universitní tiskárna UP v Olomouci, Olomouc.

World Gold Council (2020): Historical mine production. Metals Focus; Council, https://www. gold.org/goldhub/data/historical-mine-production (14. 5. 2020). 
54 GEOGRAFIE 127/1 (2022) / J. KOLEJKA

\section{ORCID}

JAROMÍR KOLEJKA

https://orcid.org/0000-0003-3927-4060 